\title{
Religion, the Public Good, and the Research University
}

\author{
Richard A. Rosengarten
}

I am delighted to be with you today and to have this opportunity to share with you some thoughts about "Religion, the Public Good, and the Research University." Of course it is important to acknowledge at the outset that any one of these terms probably merits at least the full thirty-five minutes of this speaker's time and also the fifteen minutes allotted today for discussion. So I am not going to attempt to do justice to any one of the three. Rather I am interested in their intersection and what that might itself create.

Is there a place where religion, the public good, and the research university intersect? I believe that there is; and I propose in what follows to try to describe that place for you. As an intellectual location, what I will be describing is a mental rather than a physical space. It is attitudinal. Nonetheless it most emphatically is a space. It is of interest itself, but it is also, to resort to metaphor, the "core" for what makes civil society possible. So this mental space has purely intellectual interest, and getting it right is in important ways a matter of thinking clearly and well - it is a fun puzzle to work out. But it also is absolutely vital to how we live together. Its magic is this dual character, and its existence is a matter of preserving both parts of that character.

I need to note two qualifications about what follows. My frame of reference in this talk will explicitly concern the American experiment in civil society. I am aware that this is a limitation. I also fear that it could be a danger. It is a limitation that I am insufficiently versed in other versions of civil society. For that I can only acknowledge my ignorance and invite those who know more to contribute. It is a danger in that it provides an opening for misunderstanding. I hope I shall not risk this danger in what follows, but let me say here that none of what follows is meant to imply in any simple sense a commitment to the American model of democracy for the entire world com-

Richard A. Rosengarten is dean and associate professor of religion and literature in the Divinity School at the University of Chicago. He works in religion and literature, where he pursues interests in genres of narrative (especially the novel), in hermeneutics, literary theory, and aesthetics, and in the development of religious thought through the "long" eighteenth century. This lecture, which has been slightly modified, was originally delivered at Chicago's American Islamic College on 8 December 2009. He can be contacted at raroseng@uchicago.edu. 
munity. I love American democracy and consider myself privileged to be a citizen under its governance. But the world is a complex place, and I am unwilling to operate on the assumption that the form of government I enjoy and deeply love is axiomatically the best for all peoples in all places.

What is the university's research mission? The Latin poet Horace spoke to this indirectly but eloquently when he articulated the aim of epic poetry: Mores hominum multorum vidit - to see all the ways of humanity. No less an epic goal applies to the research university. All of science, all of art, and all of the professions that relate to commerce, justice, health, social welfare, domestic policy: these are the interests of the research university.

What is research? Here we can be equally brief: it is the elucidation of what is true, discerned through evidence and argument. So far as it goes, this is perfectly accurate and useful. But it is incomplete. Research is also an ethos. Our way of honoring the ethos of research at Chicago is to inflect our work with a maxim, prominently articulated in the bylaws of the university: there is no greater compliment or form of respect that you can pay to someone's idea than to submit it to the most searching and rigorous analysis. Research is also a matter fundamentally of query and dispute, of the engaged argument, and of a system in which criticism always has a role to play. This can be overdone, as my colleague Wendy Doniger quite brilliantly suggested at the June 2008 commencement address to Chicago graduates. But it is not, in my judgment, overdone in civil society so much as it is in academic scholarship. This ethos of research, as we shall see in our discussion of Benjamin Franklin's ideas about the Constitution, is crucial.

What is a divinity school's mission, as an active part of this research university? The answer takes its bearing from these commitments. We are devoted to understanding religion and to preparing people for professional lives in teaching and in ministry. Our central commitment is to the claim that evidence and argument are essential components of serious conversation on any topic, but perhaps especially so when the topic is religion. To the degree that we may be said to do so, we privilege religion out of the conviction that few if any dimensions of the human adventure have had, and continue to have, such comprehensive import. And we seek to address the paradox that this truth's corollary is the fact that, for all its ubiquity, religion is in fact too rarely discussed with the kind of clarity and prescience that its importance merits.

It follows that to do our job well - to give religion its full due in public conversation - we need to be an institution that can talk about religion in a variety of ways. There are two parts to this talk. One has to do with recog- 
nizing that religion can be a force for good or for ill in the world. No religion is without its virtues; none is without its vices. This is an empirical matter, and in this the scholar must be unsentimental. The second part to how we talk about religion has to do with attending to religion's sheer multi-faceted character. We need to be able to speak about religion's constructive facet, its ideas and principles that make fundamental claims about truth and the good life. We also need to be able to speak about religion's historical facet, its traditions of practice and belief that have shaped, and been shaped by, the political, the social, the geographical. And we need to be able to speak about religion as cultural phenomenon that both shapes and is shaped by art (literature, music, painting, architecture, etc.), social structure, indeed all the sets of practices and forms of behavior that characterize human communities.

I enumerate these dimensions to communicate something of the range of what can be studied when one studies religion. I want quickly to add that the real magic of research on religion dwells not in these dimensions' separation but in their complementarity. Truly interesting research crosses boundaries, and the categories of the constructive, the historical, and the cultural have their use and abuse: we can appreciate all that a religion is, but we can also dilate upon one and lose crucial parts of that religion. So, creative cross-stitching is crucial in scholarship about religion.

This is especially important with regard to their truth claims. Religions are overt and explicit about their existential claim: it is impossible to study a religion well without experiencing its pull on you. To really study a religion, to encounter it, means that the thing you study studies you in return. The philosopher Emmanuel Levinas has a useful formulation: it returns your gaze. I know of no subject of study where this is as explicit as it is when the subject is religion. An interesting corollary to this is that those who teach religion and those who are religious leaders must know how they themselves respond to this claim, this returning of the gaze, if they are to excel at their chosen work. Ministry students, in my experience at Chicago, tend to grasp the truth of this more immediately than do their counterparts in doctoral study: you have to know what you yourself think about religion to engage it professionally.

In sum, then, the mission of the divinity school in the research university is to produce scholarship on religion that is fully attendant to its dimensions as a manifold human phenomenon. In doing so, this research must recognize religion's capacity to engage anyone existentially, whether their response is utter embrace, complete revulsion, or, far more commonly, 
something in between. And this research must proceed with rigorous adherence to the highest standards of evidence and argument, to ensure that the conversation about our responses to this multivalent, fascinating, and deeply complex dimension of human life is appropriately disciplined.

This is the work of the research university in relation to religion. How does this interact with civil society to create a particular mental space? I want to answer this question with two all-too-brief exercises in the topic. The first invokes a story, the second a controversy. Together they may suggest something of the powers and also of the limits of this core space and, I hope, some of its essential nature to our society, why it truly is its "core."

The story I would have you consider is the greatest satire in the English language: Jonathan Swift's Gulliver's Travels. Swift's Travels famously concludes with a final voyage in which Lemuel Gulliver travels to "the land of the Houhynhymns," a community consisting of two classes: an oligarchy of horses who rule, and a rebellious servant class of small, ape-like beings the horses have designated as "yahoos." In the course of his time in this land, Gulliver becomes utterly loyal to and admiring of the Houhynhymns and their rationally ordered lives and civil society. But he is then banished by them when they conclude that he is in fact a yahoo with a brain and thus could lead a rebellion and overturn their social order. A distraught Gulliver complies and eventually returns home to England. But once there he literally becomes a "neigh sayer," shunning its civil society for the company of horses in a barn, with whom he passes as much time as he can in rational conversation.

How are we to understand Gulliver's experience with the Houhynhymns and his continued allegiance and eventual self-ostracization despite their overt rejection of his person? Any answer is, of course, complex. It does seem clear that Swift wants his readers to reckon with the fact that neither the hyper-rational horses nor the brutely instinctive yahoos represent fully realized humanity. It is also clear that Gulliver, who might represent some combination of these natures, emphatically allies himself, and not, incidentally, his self-understanding, with the former. Swift does give Gulliver one moment of equipoise - one time when he is able to marry reason and emotion, head and heart. In it, Gulliver appeals the decision to banish him by suggesting that true justice requires mercy. Swift here renders Gulliver both incisive and eloquent. Yet the moment is both fleeting and ineffectual.

Swift's tale is rarely invoked in discussions of religion, but it should be. With regard to the Houhynhymns, Gulliver behaves like a member of what 
we would call a cult. He deploys the rituals of those horses when he returns to England. Swift thus demonstrates for us the dangers in an uncritical adoption of tradition. Yet in highlighting Gulliver's appeal at the time of his banishment - a call that justice be tempered with mercy - Swift also illustrates for the reader what Abraham Lincoln would later term "the better angels of our nature."

The difficulty for all readers of Swift, particularly for divines who study religion, is that he leaves us to draw the conclusions. This is an index of his art: it compels us to think harder than we otherwise might about both whether, and if so how, religions can achieve Gulliver's momentary insight and eloquence and then sustain them over time. The ready-to-hand answer is that religions, in their theories and their practices, are purposeful, even supervisory. Creed and code combine to encourage focus on what is true and good and beautiful. The aim is thus to establish conditions in which the appeal of a Lincoln - the continual recourse to justice tempered with mercy - is at least regularly recalled and honored. The danger is to become like the Houhynhymns, whose justice knows no mercy and thus is not justice.

This danger - which we might term the danger of ideology, the danger of so emphasizing one aspect of the truth that its remainder is forgotten and the whole thus perverted - is brilliantly addressed by Swift in his depiction of the yahoos. Here criticism and irony become crucial counterpoints to purpose and supervision. Swift reveals through Gulliver the close connection between devotion and contempt, even the way in which one feeds upon the other. To avoid Gulliver's fate we need to avoid this particular, if all too human, equation. Swift helps us by underscoring empirically the connections Gulliver denies: the yahoo females uninhibitedly express their sexual attraction to Gulliver, and Gulliver himself continually, if at first unwittingly and then reluctantly, notes their shared physiognomy.

To fully grasp what Swift shows in Gulliver, here again we might take recourse, but this time, contrastively, to Lincoln: Gulliver's resolute stigmatization of the yahoos is the opposite of Lincoln's steadfast refusal to demonize the Confederacy during the Civil War. Swift's counsel about religion would appear to suggest that creed and code must always be modulated by scrupulous attention to any effort to demonize the "other." In this sense, civil society and religion can - and must - be complementary. Given the rarity of Lincolns and of Swifts in our midst, it behooves us to recall their examples as we make our way forward.

This is an imaginative way to evoke what the core space of religion, public life, and the research university might be like. A second way to describe 
this space, more in historical and propositional than in literary and imaginative terms, is to invoke a phrase: the "faith of our fathers." For Americans this phrase can have a double resonance. It references both the founders of the United States of America and it also is the source of that "holy faith" of which Christian hymnody proclaims the singer's fealty unto death. This double legacy, with all its implications - the exclusivist reference to Christianity, the questions of the extent of citizenship, the establishment of religion - has been pivotal to the nation's history. (Its omnipresence is only heightened, as we have seen, in the year of a presidential election.) How might we think well about "the religion of the republic" in this new century whose advent is so variously challenged, not to say troubled? In a world that is smaller than ever and in which our information about the claims to faith of myriad institutions - not solely religious or political ones - is so detailed, how does one talk about the "faith" citizens might have in their nation?

These are urgent questions, but their answer today is embroiled far too exclusively in the adjudication of specific disputes about, for example, prayer in schools. At the time of the founding of this nation, however, the phrase "religion" had a significantly varied reference in the hands of those, like Benjamin Franklin, who were deists and distinguished between belief in God and the theologies of the Christian religions (note the plural).

Franklin's own idea of faith links it not to a particular religious tradition, but to an attitude toward ideals and their realization. For him, republican faith has as its object the nation's Constitution. But he was clear that the faith was directed not to the document itself, but to the ideals to which it offers partial declaration. Indeed, for Franklin the religions were themselves exemplary of misplaced or overreaching faith. The chief difference, he remarked in his speech endorsing the new Constitution on September 17, 1787, between the doctrines of the Roman Catholic and the Anglican churches, was that "the Romish Church is infallible, and the Church of England is never in the wrong."

Franklin's republican faith had another, parallel antithesis: the habits of individuals. What he deplored in these "Sects" he found abundantly present as well in his fellow creatures of God, "the many private persons (who) think almost as highly of their own Infallibility as that of their Sect." Whatever republican faith might mean, for Franklin it must not partake of the certitude of infallibility. In doctrine, whether institutional or personal, resided despotism rather than democracy.

Republican faith, then, is the antidote of doctrinal faith precisely because doctrine implies infallibility. One might wonder what Franklin 
would have made of John Henry Newman's later concept of the development of doctrine; whatever the answer, we can be sure that he would only have embraced it if, and when, he was assured that development precluded dogmatism.

Today our discussions of religion and democracy focus on matters of church and state and what sort of wall should exist between them in American public life. Franklin's notion of republican faith suggests that we would do better to consider the quality of the faith that is the prerequisite even to such adjudications. Individuals and institutions, whether political or religious, hold in common a predilection for settled opinion. For Franklin, such established creeds, whether by church or by state, were in fact despotic and thus the antithesis of democracy.

To guard against both tendencies in our behavior and our institutions is to promote and preserve the civility that is essential to our common life. The common religion of our republic is thus the resistance of all dogmatisms. In that way, and that way alone, we may retain the benisons of republican government our fathers bequeathed us. And this may be the ultimate act of faith - to enshrine values of the past in the present, for the benefit of the future.

$* * *$

Let me close by returning to one of my three words. The etymology of the word religion is commonly traced to one of two Latin words: relegere ("to read over again") or religare ("to bind"). The latter came to be favored as originary due to its demonstrable early connection with those monastic Christians who were bound by orders and were called religious. I instinctively demur from the conundrum: the religions call us to re-read, and they also bind us. They ask us to return again to the expressions of truth that we take to be fundamental, and they draw us into a relationship of submission to them. When we do that, we are living at this fundamental "core" and we are responding to what is deepest in us as human beings - and, not incidentally, to what is most basic to the fabric of our society. 